\title{
GYNYBINE் MEDICINA LIETUVOS SVEIKATOS APSAUGOJE: GYDYTOJŲ GYNYBINIŲ REAKCIJŲ FORMAVIMASIS
}

\author{
Liutauras Labanauskas \\ Lietuvos gydytojų sąjungos prezidentas \\ Lietuvos sveikatos mokslų universiteto ligoninès Kauno klinikos \\ Vaikų gastroenterologijos sektorius \\ Eivenių g. 2, LT-3007 Kaunas, Lietuva \\ Telefonas (+370 5) 2731400 \\ Elektroninis paštas Liut.L@takas.lt
}

\section{Viktoras Justickis}

Mykolo Romerio universiteto Socialinès politikos fakulteto Psichologijos katedra Ateities g. 20, LT-08303 Vilnius, Lietuva

Telefonas (+370 6) 1533289

Elektroninis paštas justickv@takas.lt

\author{
Aistė Sivakovaitė \\ Lietuvos gydytojų sąjunga \\ J. Basanavičiaus g. 8A-3, LT-01118 Vilnius, Lietuva \\ Telefonas (+370 5) 2731400 \\ Elektroninis paštas lgs@takas.lt
}

Pateikta 2013 m. birželio 15 d., parengta spausdinti 2013 m. rugsèjo 20 d.

$$
\text { doi:10.13165/SPV-13-1-5-09 }
$$

\section{Santrauka}

Straipsnyje toliau pristatomi 2440 Lietuvos gydytoju tyrimo (2011-2012) rezultatai. Ankstesniame straipsnyje buvo pateikti bendrieji tyrimo rezultatai ${ }^{1}$, o šiame nagrinejami gydytoju gynybinés reakcijos ypatumai, priklausomybè nuo profesines specializacijos ir individuliu gydytojo, paciento bei klinikinès situacijos požymių.

Analizuojant gynybinių reakcijų skirtumus pagal specialybes, nustatyta, kad aukštas gynybiniu reakcijų lygis büdingas visoms tirtoms gydytoju specialybèms. Taigi mūsų sveikatos apsaugos sistemoje nèra saugiu specialybiu, kuriu atstovai nenaudotu gynybos nuo galimo teisinio persekiojimo priemonių. Tyrimo duomenys taip pat leido išskirti lengviausiai „gynybos

$1 \quad$ Labanauskas, L.; Justickis, V.; Sivakovaite, A. Gynybinès medicinos reiškinių paplitimas Lietuvoje (pagrindiniai 2440 Lietuvos gydytojų tyrimo rezultatai). Sveikatos politika ir valdymas. 2011, 1 (3): 158-169. 
medicinos" pažeidžiamas gydytoju specialybes (bendrosios praktikos, vidaus ligu gydytojai, pediatrai, neurologai).

Svarbus tyrimo rezultatas - didelis gynybiniu reakciju skirtumas (išsibarstymas) tos pačios specialybès gydytoju grupeje. Paaiškejjo, kad priklausomai nuo individualiu gydytojo ir paciento asmenybių bruožu bei konkrečios klinikinès situacijos ypatumų, net ir tos pačios specialybès gydytojai gali reaguoti labai skirtingai. Siekiant išaiškinti squveiką tarp šiu ypatumų buvo atlikta faktoriné (pagrindines komponentès metodu su Oblimino rotacija) analizé. Šios analizés rezultatai leido nustatyti pamatini gydytojo ir paciento reakciju squeikos vaidmeni, atsirandant gynybos reakcijoms. Taip pat pasiūlyti priemones, galinčias klinikinès situacijos lygiu (psichologiniu žiniu bei igūdžių, mediacijos taikymo ir kt.) sumažinti gynybinès medicinos apraiškas.

Reikšminiai žodžiai: gynybinè medicina, gydytoju gynybinès reakcijos, klinikinè situacija, gynybinès medicinos reiškinių prevencija.

\section{Ivadas}

„Gynybinė medicina“ - tai ydingas sveikatos apsaugos reiškinys, kai gydytojo dèmesio centre - ne paciento sveikata, o siekimas apsiginti nuo galimo teisinio persekiojimo iš paciento pusès ${ }^{2}$. Ji pasireiškia tuo, kad gydytojai vengia atsakingų ir sudetingų sprendimų, skiria nebūtinus tyrimus ir vaistus, reikalingus vien gydytojui apsidrausti ir pacientui nuraminti, papildomai siunčia pas kitus specialistus konsultuotis, reikalauja, kad pacientas pasirašytų ivairiausius dokumentus, siekdami apsidrausti nuo galimos atsakomybès ${ }^{3,4,5,6,7}$.

Svarbiausia šio reiškinio priežastis - neadekvatus gydytojo teisinės atsakomybės sureguliavimas, kai reikalavimai gydytojui iš esmès viršija jo galimybes. Toks reikalavimų gydytojui ir jo galimybių neadekvatumas atsirado dèl sparčiai dabartiniame pasaulyje augančių reikalavimų gydytojui ir ženkliai atsiliekančių gydytojo galimybių juos vykdyti ${ }^{8}$. Užsienio šalyse atlikti tyrimai parode šio reiškinio paplitimo pasaulyje mastąa

Lietuvos gydytojų sąjunga ir Mykolo Romerio universiteto mokslininkai kartu atlikto pirmą šio reiškinio platų tyrimą Lietuvoje - 2440 gydytojų apklausą.

Šio reiškinio prigimtis ir užsienio šalyse atliktų tyrimų rezultatai smulkiai aptarti ankstesniame straipsnyje $\mathrm{e}^{10}$. Tyrimo organizacija, jo metodika, taip pat bendrieji šio tyrimo rezultatai, apibūdinantys bendrą "gynybinès medicinos“ paplitimą Lietuvoje, pristatyti ir aptarti

2 Labanauskas, L.; Justickis, V.; Sivakovaite, A. I̦statymo ịvykdomumas. Šiuolaikinè gydytojo atsakomybès didinimo tendencija. Socialiniu mokslu studijos. 2010, 4(8): 89-107.

3 Catino, M.; Celotti, S. The problem of defensive medicine: two Italian surveys. Studies in Health Technology Information. 2009, 148: 206-221.

4 Esposto, A. Tort Reform, Defensive Medicine, and the Diffusion of Diagnostic Technologies. Eastern Economic Journal. 2008, 34: 141-157.

5 Kessler, D.; McClellan, M. Do doctors practice defensive medicine? Quarterly Journal of Economics. 1996, 111(2): 353-390.

6 Studdert, D. M. Defensive Medicine Among High-Risk Specialist Physicians in a Volatile Malpractice Environment. JAMA. 2005, 293: 2609-2617.

7 Xiao-Yang, Chen. Defensive Medicine or Economically Motivated Corruption? A Confucian Reflection on Physician Care in China Today. Journal of Medicine and Philosophy. 2007, 32: 635-648

8 Labanauskas, L.; Justickis, V.; Sivakovaite, A., supra note 2, p. 89-107.

$9 \quad$ Ibid.

10 Ibid. 
atskirame straipsnyje ${ }^{11}$. Pagrindinè išvada - didelis „gynybinès medicinos“ paplitimas ir neigiamas poveikis mūsų sveikatos apsaugos sistemai.

Kaip minèta, ankstesniame straipsnyje pristatyti tik bendrieji tyrimo rezultatai, o šio straipsnio tikslas - išnagrinėti gydytojų gynybinių reakcijų ypatumus, priklausomai nuo ju specialybės ir atskiro gydytojo, paciento ir klinikinès situacijos ypatumų. Šių reiškinių tyrimas mūsų šalyje atliekamas pirmą kartą, kas garantuoja jo rezultatų naujumą. Jo aktualumas išplaukia iš tiriamo reiškinio paplitimo mūsų sveikatos apsaugoje ir jo neigiamo poveikio jos veiklai ir ypač sveikatos apsaugos paslaugų kokybei.

Tyrimo medžiaga buvo surinkta, atliekant reprezentatyvią 2440 Lietuvos gydytojų apklausą. Respondentams buvo pateikta tyrimo autorių sudaryta anketa gynybinès medicinos reiškiniams tirti. Anketoje 58 klausimai.

Pirmają klausimu grupę sudarè klausimai apie atskiras gydytojų gynybines reakcijas veiksmus, kuriais gydytojas siekia apsiginti nuo galimo teisinio persekiojimo.

Gydytojai buvo apklausti, ar taiko ir kiek dažnai penkis gynybos nuo galimo teisinio persekiojimo veiksmus:

1. Vengia „rizikingu“ pacientu. Tai pacientai, su kuriais dirbant dèl vienų ar kitų priežasčių gydytojui kyla pavojus, kad jis taps teisinio persekiojimo objektu. Buvo klausiama, ar dažnai vengiama pacientų, kurių būklè sunki, kurie serga pavojingomis ligomis, kurių vaizdas yra neaiškus ir apsunkina diagnozę, taip pat pacientų, kurių elgesys rodo, kad jie linkę skųstis.

2. Vengia atlikti rizikingus veiksmus ir procedūras. Būtinybè atlikti šiuos veiksmus gali kilti kiekvienu atveju, kai susirgimo pobūdis ir paciento būklè reikalauja ryžtingų ir atsakingų gydytojo sprendimų. Gydytojams buvo užduotas klausimas, kiek dažnai jie vengia tokių sprendimų norèdami apsisaugoti nuo galimos teisinès atsakomybès.

3. Nebūtini siuntimai pas kitus specialistus. Buvo klausiama, kiek dažnai pacientas siunčiamas pas kitą specialistą tik tam, kad gydytojas išvengtų atsakingesnio sprendimo ir pavojaus būti apkaltintam už gydymo nesèkmę.

4. Nebūtinų tyrimų skyrimas. Gydytojai buvo klausiami, kiek dažnai skiria nebūtinus tyrimus vieninteliu tikslu - apsisaugoti nuo kaltinimo, kad pacientas buvo ištirtas nepakankamai.

5. Nebūtinų vaistų skyrimas. Perteklinių vaistų skyrimas norint apsisaugoti nuo galimų kaltinimų, kad nebuvo išnaudotos visos medikamentinio gydymo galimybės.

Atsakymų i pateiktus klausimus pagrindu buvo apskaičiuotas bendras gydytojo gynybinès reakcijos rodiklis (GRR). Gydytojai įvertino kiekvieną gynybinès reakcijos aspektą 4 balų sistema (1 - niekada taip nereaguoju, 2 - retai, 3 - kartais, 4 - dažnai). GRR sudarè visų vertinimų suma kiekvienam gydytojui.

Antraja grupę sudarè klausimai, apibūdinantys klinikinès situacijos (taip pat ir paciento asmenybès) ypatumus, sukeliančius GR (žr. 2 lentelę).

Trečioji grupé - klausimai, rodantys gydytojo individualias (psichologines, emocines) reakcijas (žr. 3 lentelę).

Atlikta reprezentatyvi tikslinè dalyvių atranka, kad rezultatai atspindètų visų pagrindinių medicinos specialybių gydytojų nuomonę. Atrinkti 26 ịvairių specialybių gydytojai, atstovaujantys visiems trims sveikatos priežiūros sistemos lygiams bei visiems pagrindiniams sveikatos sistemos įstaigų tipams.

11 Labanauskas, L.; Justickis, V.; Sivakovaitè, A., supra note 1, p. 158-169. 
Duomenu apdorojimas. Apklausos rezultatams apdoroti buvo panaudoti Pearsono linijinès (moment-product) porinès ir dalinès koreliacijos koeficientai ${ }^{12}$.

Siekiant išaiškinti paslèptus (latentinius) pamatinius veiksnius, lemiančius GR, buvo atlikta faktorinè analizè pagrindinès komponentès metodu su rotacija taikant tiesinị oblimin metodą. Šie metodai taikomi biomedicinos tyrimuose bei duomenų analizejje ${ }^{13},{ }^{14}$.

\section{Skaičiavimai atlikti PASW 18 sistemoje.}

\section{Rezultatai}

\subsection{Gydytojų gynybinè reakcija priklausomai nuo jų specialybės}

1 paveikslas ir 1 lentelè rodo bendro gydytojo gynybinių reakcijų rodiklio (GRR) vidurkius priklausomai nuo jų specializacijos. Užtikrinant duomenų statistini patikimumą pateikiamos tik tos specialybės, kur atsakiusiųjų skaičius viršija 40 respondentų. Lentelès skiltyje „Vidurkiai“ pateikti duomenys rodo specialybės gynybinių reakcijų stiprumą, o skiltyje „Vidurkių pasikliautini intervalai“ pateiktos reikšmės rodo GRR dydžių „išsibarstymą“, t. y., kiek pagal gynybinių reakcijų stiprumą vienos specialybės gydytojų reakcijos skiriasi tarpusavyje ${ }^{15}$.

1 lentelè . Gydytojų gynybinè reakcija priklausomai nuo specialybès

\begin{tabular}{|l|c|c|c|c|}
\hline \multicolumn{1}{|c|}{ Gydytojų specialybès } & Vidurkiai & $\begin{array}{c}\text { Standartiniai } \\
\text { nuokrypiai }\end{array}$ & $\begin{array}{c}\text { Atsakiusiųu } \\
\text { skaičius }\end{array}$ & $\begin{array}{c}\text { Vidurkiu } \\
\text { pasikliautini } \\
\text { intervalai } \\
\mathbf{( 9 9} \%)\end{array}$ \\
\hline Akušeriai-ginekologai & 9,55 & 2,82 & 222 & $\pm 0,15$ \\
\hline Anesteziologai-reanimatologai & 8,38 & 3,37 & 131 & $\pm 0,18$ \\
\hline Bendrosios praktikos gydytojai & 11,73 & 3,30 & 268 & $\pm 0,17$ \\
\hline Chirurgai & 9,68 & 3,42 & 98 & $\pm 0,18$ \\
\hline Otorinolaringologai & 9,70 & 3,42 & 61 & $\pm 0,18$ \\
\hline Neonatatologai & 8,53 & 3,35 & 45 & $\pm 0,17$ \\
\hline Neurologai & 10,47 & 3,46 & 49 & $\pm 0,18$ \\
\hline Odontologai & 9,20 & 3,11 & 60 & $\pm 0,18$ \\
\hline Oftalmologai & 8,47 & 2,33 & 62 & $\pm 0,12$ \\
\hline Radiologai & 7,86 & 3,24 & 42 & $\pm 0,17$ \\
\hline Pediatrai & 10,15 & 3,28 & 228 & $\pm 0,17$ \\
\hline Vidaus ligų gydytojai & 10,67 & 3,51 & 235 & $\pm 0,17$ \\
\hline Iš viso & $\mathbf{9 , 8 1}$ & $\mathbf{3 , 3 7}$ & $\mathbf{2 1 4 8}$ & $\pm \mathbf{0 , 1 7}$ \\
\hline
\end{tabular}

12 Katz, M. H . Study Design and Statistical Analysis: A PracticalGuide for Clinicians. CambridgeUniversityPress, 2006.

13 Abdi, H.; Williams, L. J. Principal component analysis. Wiley Interdisciplinary Reviews: Computational Statistics. 2010, 2: 433-459.

14 Justickis, V. Data mining. Handbook of electronic security and digital forensic London - New Jersey Bejing, 657-692.

15 Bohm, G.; Zech, G. Introduction to Statistics and Data Analysis for Physicians. Verlag Deutsches Elektronen-Synchrotron. 2010, 201-218. 
1 lentelès duomenys rodo, kad mūsų medicinoje nèra saugių specialybių, tai yra tokių, kur gydytojas nebijo teisinio persekiojimo ir dèl to nenaudoja gynybos priemonių. Mažiausia nustatyta gynybinès reakcijos reikšmè 7,86 (radiologai), o tai - labai stipri gynybinè reakcija. Visų kitų specialybiu gynybinès reakcijos stiprumas yra panašus ir svyruoja gana siauru intervalu nuo 8,47 (anesteziologai-reanimatologai) iki 11,73 (bendrosios praktikos gydytojai).

Taigi visoms gydytojų specialybėms būdingas ženklus gynybinès reakcijos lygis.

Gauti duomenys leidžia išskirti ir labiausiai pažeidžiamas specialybes. Stipriausios gynybinès reakcijos nustatytos tarp bendrosios praktikos $(11,7)$, vidaus ligų $(10,7)$, neurologijos $(10,47)$, pediatrijos $(10,15)$ specialybių atstovų.

Bendras šių specialybių bruožas - reikalaujama labai plati kompetencija. Bendrosios praktikos vidaus ligų gydytojams bei pediatrams tenka būti „visų amatų meistrais“, gebėti ịtarti ir diagnozuoti ypač plataus spektro ligas. Aukšti reikalavimai šių specialybių gydytojų kompetencijai skatina baimę suklysti ir atitinkamai gynybinę reakciją - apsidrausti nuo galimos klaidos pasekmių.

Šioje gydytojų grupėje pastebèta aukščiausia gynybinẻ reakcija kelia susirūpinimą, nes būtent šių specialybių atstovai pirmieji susiduria su pacientais ir yra atsakingi už tolesnị jų siuntimą pas kitus specialistus. Taigi nuo jų tikslų, motyvų ir sprendimų priklauso visos mūsų sveikatos apsaugos sistemos veiksmingumas.

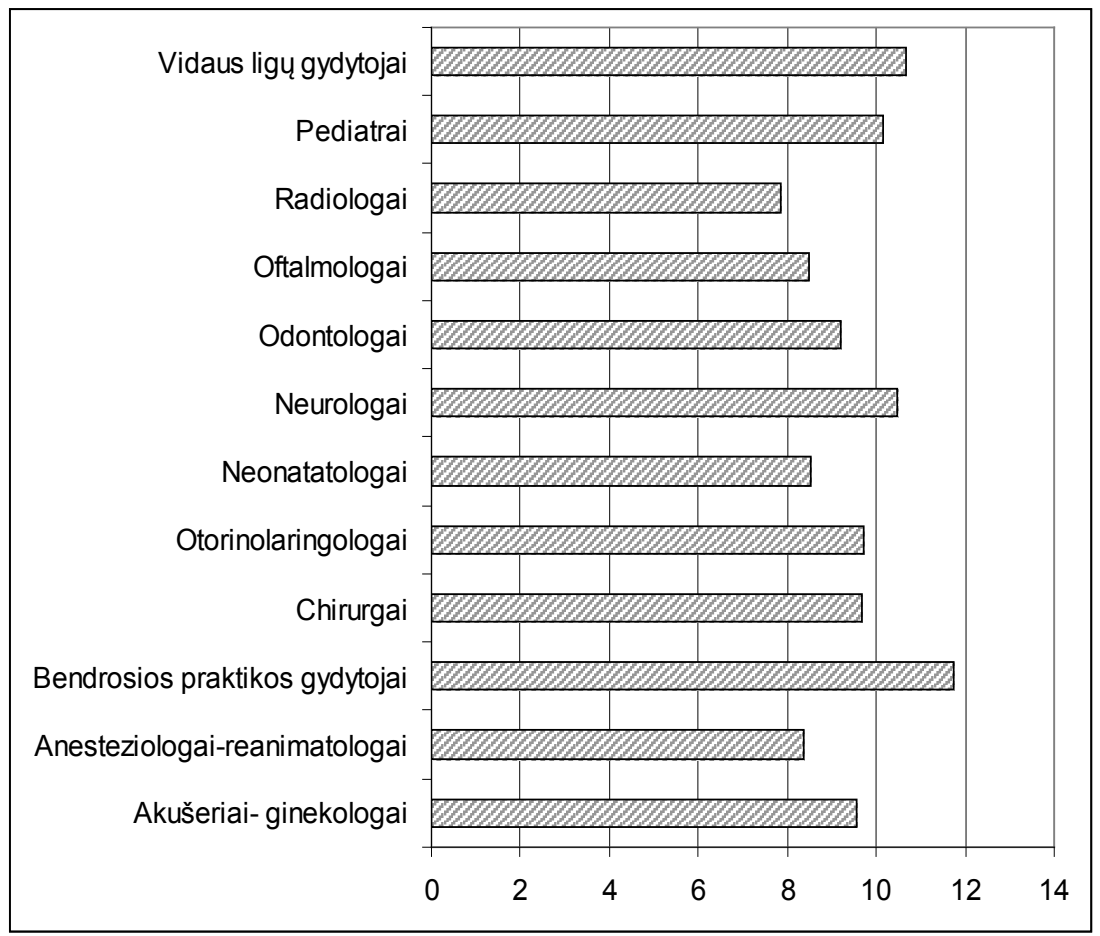

1 pav. Gydytojų gynybinè reakcija priklausomai nuo specialybès 
Labai svarbūs yra duomenys, parodantys GRR stiprumo išsibarstymą kiekvienos specialybès rèmuose (1 lentele - skiltis „Standartiniai nuokrypiai“). Šis rodiklis parodo, kad kiekvienos specialybès GRR stiprumo vidurkis tik labai bendrai apibūdina šios specialybès gydytojų gynybines reakcijas, daugelio specialybių gydytojų GRR stiprumas ženkliai skiriasi nuo specialybės vidurkio. Pavyzdžiui, vidaus ligų gydytojų standartinis nuokrypis siekia \pm 3,5. Tai reiškia, kad nemažos vidaus ligų specialistų dalies GRR yra stipresnè ir net daug stipresnè už šios specialybės vidurkị. Reakcijų ịvairovė būdinga ir neurologams $( \pm 3,5)$, chirurgams $( \pm 3,44)$, otorinolaringologams $( \pm 3,4)$, neonatologams $( \pm 3,3)$, anesteziologams-reanimatologams $( \pm 3,38)$, pediatrams $( \pm 3,28)$, bendrosios praktikos $( \pm 3,26)$ gydytojams.

Taigi, nors gynybinių reakcijų stiprumas tam tikru laipsniu ir priklauso nuo specialybės, tačiau tos pačios specialybės gydytojai gan įvairiai reaguoja i̇ veiksnius, sukeliančius GRR, stebimas didelis GRR ,išsibarstymas“.

\subsection{Veiksniai, sukeliantys individualius psichologinius skirtumus tarp vienos specialybės gydytojų}

Tiriamieji buvo prašomi ịvertinti tam tikrus klinikinès situacijos aspektus, nurodant, kiek jie skatina juos taikyti gynybos priemones ir apibūdinti savo emocines reakcijas ị jas. 2 ir 3 lentelès duomenys parodo koreliacinius ryšius tarp šių momentų ir gydytojo gynybinès reakcijos stiprumo.

2 lentelè. Gynybinès reakcijos stiprumo priklausomybè nuo klinikinès situacijos ypatumų

\begin{tabular}{|c|c|}
\hline Klinikinės situacijos ypatumai & $\begin{array}{c}\text { Gynybinès reakcijos stiprumas } \\
\text { (koreliacijos koeficientai) }\end{array}$ \\
\hline 1. Neturite tiek laiko, kiek reikalauja paciento būklè & $0,335^{\star *}$ \\
\hline 2. Pernelyg sudetingas ir painus atvejis & $0,317^{\star *}$ \\
\hline 3. Pacientas yra ịtakingas, žinomas asmuo & $0,390^{* *}$ \\
\hline $\begin{array}{l}\text { 4. Prièmimo metu pacientas leidžia Jums suprasti, kad gerai } \\
\text { išmano įstatymus }\end{array}$ & $0,387^{\star \star}$ \\
\hline 5. Pacientas labai reiklus & $0,414^{\star *}$ \\
\hline 6. Konfliktinis paciento charakteris & $0,460^{* *}$ \\
\hline 7. Pacientas abejoja kiekvienu Jūsų veiksmu ir sprendimu & $0,427^{\star *}$ \\
\hline 8. Pacientas pats nelabai vertina savo sveikatą & $0,245^{\star *}$ \\
\hline 9. Pacientas aiškiai blogos nuotaikos & $0,313^{* *}$ \\
\hline
\end{tabular}

Pastaba. ${ }^{* *}$ - statistinis patikimumas 0,001 lygiu

3 lentelè. Gydytojo reakcija ị klinikinès situacijos ypatumą. Darbas su itin nepatikliu pacientu

\begin{tabular}{|l|c|}
\hline Turite reikalą su labai nepatikliu pacientu. Kaip jaučiatės? & $\begin{array}{c}\text { Gynybinès reakcijos stiprumas } \\
\text { (koreliacijos koeficientai) }\end{array}$ \\
\hline 1. Niekaip. Man tas pats & 0,017 \\
\hline 2. Suprantu ji. Juo dètas irgi nelabai tikèčiau gydytojais & 0,073 \\
\hline 3. Nerimą & $0,296^{\star *}$ \\
\hline 4. Suirzimą & $0,335^{\star *}$ \\
\hline
\end{tabular}




\begin{tabular}{|l|c|}
\hline Turite reikalą su labai nepatikliu pacientu. Kaip jaučiatės? & $\begin{array}{c}\text { Gynybinės reakcijos stiprumas } \\
\text { (koreliacijos koeficientai) }\end{array}$ \\
\hline 5. Didesnį atsakomybės jausmą & $0,136^{\star}$ \\
\hline 6. Tai man trukdytų normaliai dirbti & $0,305^{\star *}$ \\
\hline 7. Norą greičiau jo atsikratyti & $0,400^{* *}$ \\
\hline $\begin{array}{l}\text { 8. Kaltès jausmą. Žinau, kad jis teisus, bet negaliu jam duoti } \\
\text { visko, ko jam reikia }\end{array}$ & $0,210^{\star *}$ \\
\hline 9. Antipatiją & $0,315^{\star *}$ \\
\hline 10. Pradedu mažiau jị užjausti, tampu abejingas jam & $0,316^{* *}$ \\
\hline 11. Darausi atsargesnis ir apdairesnis & $0,296^{* *}$ \\
\hline
\end{tabular}

Pastaba. ${ }^{* *}$ - statistinis patikimumas 0,001 lygiu; ${ }^{*}$ - statistinis patikimumas 0,01 lygiu

2 lentelès duomenys rodo labai glaudų gydytojo gynybinès reakcijos ryši su klinikinès situacijos ypatumais. Ši reakcija tuo stipresne, kuo konfliktiškesnis $(0,460)$, reiklesnis $(0,427)$ nepatiklesnis $(0,427)$ yra pacientas. Šie koreliacijos koeficientai yra aukščiausi iš visų, nustatytų mūsų tyrimo metu.

Tai rodo, kad stipriausias gynybines reakcijas skatina paciento asmenybė. Negalima pamiršti ir objektyvių gynybinès reakcijos priežasčių - nepamatuoti reikalavimai gydytojui, jų ir gydytojo realių galimybių neatitikimas ${ }^{16}$. Tačiau būtent su paciento asmenybe susietas, kupinas įtampos, nepasitikejimo santykis su gydytoju yra svarbiausias gynybinès reakcijos katalizatorius, verčiantis jas pasireikšti itin stipriai.

Labai stiprų poveiki gydytojui turi ir kiti veiksniai. GR suintensyvejja, jei pacientas yra įtakingas, žinomas asmuo (0,390), jeigu prièmimo metu pacientas leidžia gydytojui suprasti, kad gerai išmano ịstatymus $(0,387)$. Visų minėtų gan ịvairių gynybinę reakciją sustiprinančių veiksnių bendras bruožas yra grèsmė gydytojui, kylanti iš įsitikinimo, kad nesèkmès atveju bus nubaustas kur kas griežčiau.

Du kiti gynybinę reakciją sustiprinantys veiksniai - atvejo sudėtingumas $(0,335)$ ir laiko trūkumas $(0,311)$ - veikia kitaip. Jie apsunkina teisingo sprendimo prièmimą ir kartu padidina gydytojo klaidos tikimybę, skatina baimę suklysti ir siekị išvengti būtinybès priimti pavojingą sprendimą.

Tačiau gynybinės reakcijos stiprumas priklauso ne tik nuo atskiros klinikinės situacijos ypatumų, bet ir nuo paties gydytojo reakcijos ypatumų.

3 lentelè rodo, kaip gydytojai reaguoja, kai jų pacientas yra labai nepatiklus, abejoja kiekvienu gydytojo veiksmu. Reaguojama labai įvairiai, priklausomai nuo to, kokias emocijas gydytojui sukelia paciento nepasitikejjimas. Pirmiausia, atkreiptinas dèmesys į neutralią gydytojo reakciją („Niekaip. Man tas pats“) ir jų poveikį. 3 lentelès duomenys rodo, kad šiuo atveju koreliacija tarp šio atsakymo ir gynybinès reakcijos stiprumo artima nuliui $(0,017)$. Tai reiškia, kad gydytojui nereaguojant emocionaliai ị paciento nepasitikejimą, pastarasis nedaro jokio poveikio gynybos reakcijai.

Panašų poveikị daro ir teigiamas gydytojo požiūris ị paciento nepasitikẻjimą („Suprantu jị. Juo dètas, irgi nelabai tikèčiau gydytojais“). Čia matome labai silpną koreliacinị ryši tarp šio požiūrio ir gynybinès reakcijos stiprumo $(0,073)$.

Tuo tarpu bet kokios kitos emocinès gydytojo reakcijos smarkiai sustiprina GR. Šios reakcijos ypatingas stiprumas pastebimas gydytojų grupeje, kuriems paciento nepasitikejimas

16 Labanauskas, L.; Justickis, V; Sivakovaite, A., supra note 1, p. 158-169. 
sukelia norą greičiau jo atsikratyti $(0,400)$, suirzimą $(0,335)$, abejingumą pacientui $(0,316)$, antipatiją (0.315), nerimą $(0,296)$. Tai trukdo gydytojui dirbti $(0,305)$.

Ypač įdomi tokia gydytojo reakcija - „didesnis atsakomybès jausmas“. Labai paplitęs yra požiūris, kad kuo didesnè gydytojo atsakomybè, tuo geriau jis dirba. Vadovaujantis šiuo požiūriu siekiama didinti gydytojo atsakomybę, leidžiant naujus teisės aktus ir griežtinant sankcijas. Mūsų tyrimas parodè, kad atsakomybès jausmas daro ir neigiamą poveikị, sustiprinant gynybines gydytojo reakcijas $(0,136)$.

\subsection{Veiksniai, lemiantys sąveiką tarp klinikinès situacijos, gydytojo individualių reakcijų ir gynybinès reakcijos}

Tyrimas parodè labai svarbią individualios klinikinès situacijos ir psichologinių reakcijų reikšmę, sukeliant gydytojo gynybinę reakciją. Visa tai skatina nuodugniau ištirti jų sąveiką, išaiškinti kitus veiksnius, kurie turi ịtakos šiai reakcijai. Tam tikslui taikome šiuolaikinius daugiamatès statistikos metodus, leidžiančius nustatyti tokius veiksnius.

Taikyta faktorinè analizè atlikta trimis etapais.

1. Klinikinių situacijų ypatumų faktorinè analizè (žr. 4 lentelę).

2. Gydytojo psichologinių reakcijų faktorinė analizè (žr. 5 lentelę).

3. Koreliacijų tarp nustatytų vienoje ir kitoje pamatinių veiksnių.

\subsubsection{Klinikinès situacijos ypatumų faktorinè analizė}

4 lentelè. Klinikinių situacijų ypatumų faktorinès analizès rezultatai

\begin{tabular}{|l|c|}
\hline \multicolumn{1}{|c|}{ Klinikinès situacijos ypatumai } & $\begin{array}{c}\text { Klinikinės situacijos bendras } \\
\text { grèsmingumas }\end{array}$ \\
\hline Gynybinè reakcija & $0,562^{\star *}$ \\
\hline Neturite tiek laiko, kiek reikalauja paciento būklè & $0,601^{\star *}$ \\
\hline Pernelyg sudètingas ir painus atvejis & $0,679^{\star *}$ \\
\hline Pacientas yra ịtakingas, žinomas asmuo & $0,711^{\star *}$ \\
\hline $\begin{array}{l}\text { Prièmimo metu pacientas leidžia Jums suprasti, kad gerai } \\
\text { išmano ịstatymus }\end{array}$ & $0,774^{\star *}$ \\
\hline Pacientas labai reiklus & $0,832^{\star *}$ \\
\hline Konfliktinis paciento charakteris & $0,811^{\star *}$ \\
\hline Pacientas abejoja kiekvienu Jūsų veiksmu ir sprendimu & $0,686^{\star *}$ \\
\hline Pacientas pats nelabai vertina savo sveikatą & $0,669^{\star *}$ \\
\hline Pacientas aiškiausiai blogos nuotaikos & $0,731^{\star *}$ \\
\hline
\end{tabular}

Nustatytas veiksnys paaiškina 50,4 procentus bendros veiksnių variacijos.

Pastaba. ${ }^{* *}$ - statistinis patikimumas 0,001 lygiu

Kaip parodo 4 lentelès duomenys, faktorinė analizè išaiškino vieną paslèptą (latentinị) veiksnị, kuris paaiškina 50,4 procentus bendros veiksnių variacijos.

Šis veiksnys pasižymi aukštomis koreliacijomis su visais klinikinès situacijos ypatumais, sukeliančiais gydytojo gynybinę reakciją. Jo koreliacija su paciento nepatiklumu siekia net 0,832 , su konfliktiniu paciento charakteriu $-0,811$, su paciento bloga nuotaika $-0,731$, su 
paciento nepasitikejjimu - 0,669. Labai aukšti yra ir išaiškinto veiksnio koreliacijos rodikliai su visais kitais klinikinès situacijos ypatumais.

Gauti duomenys leidžia interpretuoti ši veiksnị kaip klinikinės situacijos bendrą grèsmingumą. Šis veiksnys susidaro dèl to, kad ịvairūs klinikinès situacijos ypatumai, sukeliantys gydytojo gynybinę reakciją, dažniausiai veikia kartu bei vienas kitą sustiprindami. Nepatiklus pacientas dažniausiai kartu ir konfliktiškas, ir blogos nuotaikos, ir reiklus, ir linkęs rodyti, kad gerai išmano įstatymus ir dèl to gali pridaryti gydytojui nemalonumų. Taip elgtis dažniau leidžia sau gana žinomas ir ịtakingas asmuo. Visi šie momentai tampa ypač svarbūs, jeigu atvejis sudètingas, o gydytojo laikas ribotas.

Kaip parodo 4 lentelè, šis klinikinès situacijos bendras grèsmingumas labai koreliuoja su GRR stiprumu (0,562). Darytina išvada, kad GRR ne tiek priklauso nuo tam tikrų klinikinès situacijos ypatumų (pvz., kiek konfliktiškas ar nepatiklus pacientas, kiek sudètinga situacija ir kiek turima laiko), o nuo bendro (daugelio kartu veikiančių atskirų grèsmių sukelto) grèsmingumo.

\subsubsection{Gydytojo psichologinių reakcijų faktorinè analizè}

5 lentelè parodo gydytojo reakcijų faktorinès analizès rezultatus. Ji taip pat leido išaiškinti vieną pamatinị, slypintị už visų gydytojo reakcijų ir sudarantị jų pagrindą, faktorių.

5 lentelè. Gydytojo psichologinių reakcijų faktorinès analizès rezultatai

\begin{tabular}{|l|c|}
\hline \multicolumn{1}{|c|}{$\begin{array}{c}\text { Gydytojo psichologinė reakcija dirbant su itin nepatikliu } \\
\text { pacientui }\end{array}$} & $\begin{array}{c}\text { Gydytojo bendras jautrumas } \\
\text { klinikinės situacijos grèsmingumui }\end{array}$ \\
\hline 1. Niekaip. Man tas pats & 0,023 \\
\hline 2. Suprantu jị. Juo dètas, irgi nelabai tikéčiau gydytojais & $0,287^{* *}$ \\
\hline 3. Nerimą & $0,669^{* *}$ \\
\hline 4. Suirzimą & $0,715^{* *}$ \\
\hline 5. Didesnį atsakomybės jausmą & $0,437^{* *}$ \\
\hline 6. Tai man trukdo normaliai dirbti & $0,691^{* *}$ \\
\hline 7. Norą greičiau jo atsikratyti & $0,710^{* *}$ \\
\hline 8. Kaltès jausmą. Žinau, kad jis teisus, bet negaliu jam duoti & $0,479^{* *}$ \\
\hline viso, ko jam reikia & $0,635^{* *}$ \\
\hline 10. Pradedu mažiau jị užjausti, tampu abejingas jam & $0,603^{* *}$ \\
\hline 11. Darausi atsargesnis ir apdairesnis & $0,602^{* *}$ \\
\hline
\end{tabular}

Išaiškintas veiksnys paaiškina 31,6 procentus bendros veiksnių variacijos.

Pastaba. ${ }^{* *}$ - statistinis patikimumas 0,001 lygiu

Šis veiksnys paaiškina 31,6 procentus bendros veiksnių variacijos. Jis pasižymi aukštomis koreliacijomis su paciento sukelto suirzimo $(0,715)$, nerimo reakcija $(0,669)$, noru greičiau atsikratyti paciento $(0,710)$, antipatija jam $(0,635)$. Taigi gydytojo susidūrimas su nepatikliu pacientu sukelia sudètingą emocinę reakciją, kurioje yra glaudžiai susiję neigiami jausmai nerimas, suirzimas, antipatija, abejingumas pacientui ir noras greičiausiai atsikratyti juo. Tai emocijų kompleksas, kurị gydytojui sukelia klinikinès situacijos grèsmingumas. Išaiškintam 
veiksniui buvo duotas pavadinimas „Gydytojo bendras jautrumas klinikinès situacijos grèsmingumui“.

Šis veiksnys irgi ženkliai prisideda stiprinant gydytojo gynybinę reakciją. Koreliacijos koeficientas tarp šio veiksnio ir gynybinès reakcijos stiprumo sudaro 0,575 . Be to, išaiškintas gydytojo bendro jautrumo klinikinès situacijos grèsmingumui veiksnys pasirodè glaudžiai susietas su klinikinès situacijos bendru grèsmingumo veiksniu. Jų koreliacijos koeficientas yra net 0,915 .

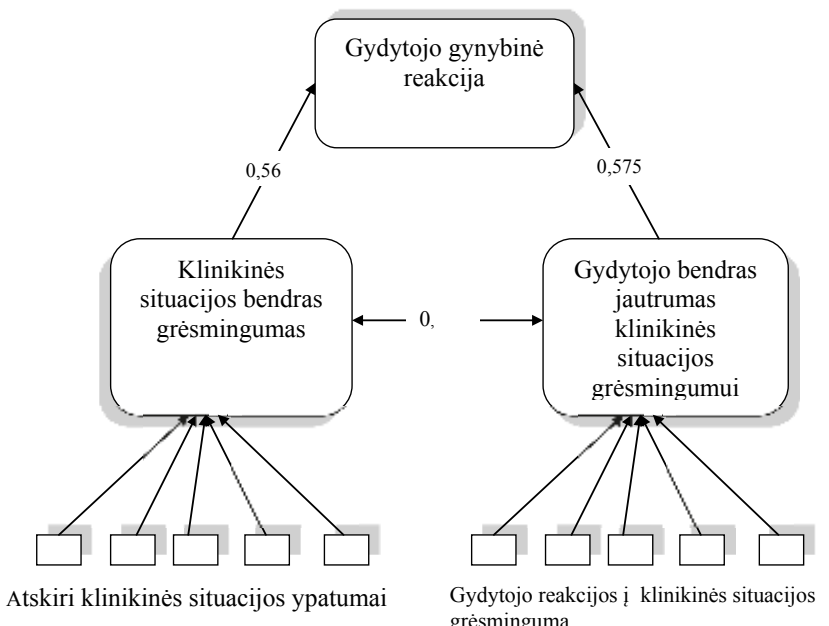

Atskiri klinikinès situacijos ypatumai grèsmingumą

2 paveikslas. Bendras sąveikos tarp minètų veiksnių mechanizmas

Tai vargu ar turètų mus stebinti. Gydytojo polinkis suvokti klinikines situacijas kaip grèsmingas ir polinkis reaguoti i jas suirzimu, antipatija, nerimu yra dvi to paties reiškinio pusès. Kuo asmuo jautresnis, tuo daugiau situacijų jis linkęs suvokti kaip grèsmingas ar sunkias. Kuo daugiau jis linkęs taip jas suvokti, tuo stipresnes emocines reakcijas tokios situacijos jam sukelia.

2 paveikslas rodo bendrą visų tirtų ir tyrimo metu išaiškintų veiksnių sąveiką.

\section{Rezultatų aptarimas}

Tyrimo rezultatai, apsvarstyti šiame straipsnyje, iš esmès papildo ankstesnius mūsų ir kitų autorių rezultatus ${ }^{17}$. Tiek mūsų, tiek kitų autorių dėmesio centre buvo teisinių ir kitų reikalavimų gydytojams neatitiktis gydytojo realioms galimybès ịvykdyti juos (ịstatymų ir kitų norminių aktų, reglamentuojančių gydytojo veiklą, neįvykdomumas). Iš to darytina išvada dèl būtinybès pakoreguoti teisinius reikalavimus, padaryti juos geriau ịvykdomus ${ }^{18}$. Nauji, šiame straipsnyje gauti rezultatai nepaneigia ankstesnių, tačiau kartu atkreipia dèmesị ị svarbias papildomas šios problemos sprendimo, ypač psichologijos, mediacijos ir kt. metodų, galimybes, švelninant gynybinès medicinos reiškinius ir pasekmes.

17 Labanauskas, L., Justickis, V.; Sivakovaite, A., supra note 2, p. 89-107.

18 Ibid. 
Nauji duomenys verčia mus atkreipti demesị i psichologinius momentus, taip pat atskleidžia santykių tarp gydytojo ir paciento reikšmę. Nepaisant bendrųjų, aukšto lygio - visuomenės mastu veikiančių teisinių, socialinių, ekonominių, organizacinių veiksnių, gynybinių reakcijų atsiradimas ypač priklauso nuo žemutinio lygio veiksnių. GR lemia gydytojo ir jo paciento santykiai konkrečioje klinikinèje situacijoje. Reakcijos priklauso nuo asmenybiu ypatumų, nuo sugebejjimo suprasti, bendrauti, bendradarbiauti, ịveikti nepasitikèjimą, sèkmingai aptarti ir spręsti kylančias problemas.

Tyrimas atskleidè, kad daliai gydytojų pavyksta sẻkmingai spręsti paciento nepasitikejjimo problemas. Šiai grupei specialistų gynybinè reakcija nekyla net kontaktuojant su nepatikliu, reikliu ir linkusiu skųstis pacientu. Gydytojas, suprantantis paciento jausmus, pripažįstantis jų natūralumą, sẻkmingiau ịveikia pacientų nepasitikejjimą. Tačiau gydytojas, suvokiantis paciento nepasitikejjimą kaip priešiškumo ir grèsmès išraišką, linkęs gintis ir vengti būsimo konflikto bei teisinio persekiojimo grèsmės. Gynybos reakcijos šiems specialistams kyla natūraliai.

Apibendrinant pirmojo ir antrojo straipsnio rezultatus, galima kalbeti apie $d v i g u b q$ gynybinès medicinos etiologiją. Remiantis šia koncepcija, gynybinès medicinos reiškinius formuoja dviejų lygių veiksniai.

Bendrasocialiniu lygiu GR sukelia teisinio reguliavimo trūkumai: teisiniai reikalavimai gydytojui didejo ženkliai greičiau nei galimybės juos įvykdyti (įstatymo ịvykdomumo problemos) ${ }^{19}$. Šiuo lygiu pagrindinė gynybinès medicinos apraiškų mažinimo priemone ịstatymų ir galimybių juos ịvykdyti tobulinimas.

Atskiros klinikines situacijos lygiu pagrindinis vaidmuo skatinant gynybinę mediciną tenka psichologiniams ir kultūriniams veiksniams. Tyrimo rezultatai formuoja išvadą, kad geri gydytojo ir paciento santykiai, supratimas sprendžiant kylančias problemas mažina tikimybę atsirasti gynybinei reakcijai. Gydytojų, dirbančių tomis pačiomis sąlygomis, gebejimas atsispirti gynybinès medicinos veiksniams ženkliai skiriasi. Tenka daryti išvadą, kad viena iš svarbiausių gynybinès reakcijos atsiradimo priežasčių yra dalies gydytojų nepakankamas psichologinis pasirengimas, gebejjimų bendrauti, spręsti konfliktus stoka.

Paciento nepasitikèjimo gydytoju problema aštrẻja. Pacientų teisių apsaugos ekspansija, visuomenejje didejjantis sveikatos vertès suvokimas skatina kritišką gydytojo darbo vertinimą. Reiklus, kritiškas, aktyviai besidominantis medicina, kartu nepasitikintis bei abejojantis pacientas - visuomenès ir sveikatos apsaugos pažangos tendencija. Paternalistinị mąstymą keičia gydytojo ir paciento bendradarbiavimo santykiai. Tačiau turètume atkreipti dèmesi ì profesinio parengimo spragas, nes, siekiant sumažinti gynybinę gydytojų reakciją, būtina ugdyti naujas kompetencijas. Svarbia priemone turètų tapti gydytojų švietimas bendravimo, komunikacijos, konfliktų sprendimo srityse. Kol kas neišnaudojamos švietimo bei psichologinès pagalbos gydytojams galimybès mažinant gynybinès medicinos apraiškas sveikatos apsaugos sistemoje. Atkreiptinas dèmesys, kad specialistams būtina pagalba ígyjant ir formuojant gebejimus, todèl šių kompetencijų ugdymas turètų būti profesinio gydytojų tobulinimo dalis.

\section{Išvados}

1. Aukštas gynybinių reakcijų lygis būdingas visų specialybių gydytojams.

2. Ypatingai aukštas gynybinių reakcijų lygis nustatytas specialybių, reikalaujančių gydytojo universalumo (bendrosios praktikos, vidaus ligų, pediatrijos), atstovų. 
3. Kiekvienos specialybės rèmuose nustatytas platus GR intensyvumo „išsibarstymas“ dideli skirtumai stebimi vienos specialybės gydytojų grupeje, jie priklauso nuo gydytojo ir paciento asmenybių bruožų, taip pat klinikinès situacijos ypatumų.

4. Išaiškinti du pamatiniai paslèpti (latentiniai) veiksniai, kurie lemia gydytojo ir paciento asmenybių, taip pat klinikinès situacijos ypatumų sąveiką. Klinikinėje situacijoje GR kyla per paslèptą pamatinị veiksnị - bendrąji klinikinès situacijos grèsmingumą. Individuali gydytojo reakcija veikia GR lygị per tarpinị pamatinį veiksnį - gydytojo bendrą jautrumą klinikinès situacijos grèsmingumui.

5. Tyrimo metu išaiškinta didele klinikinès situacijos ir gydytojų reakcijų reikšmè. Siekiant mažinti gynybinès medicinos apraiškas sveikatos apsaugos sistemoje, atskleistas poreikis tobulinti gydytojų profesinị parengimą. Neišnaudotos psichologinės pagalbos, švietimo, naujų kompetencijų ugdymo, mediacijos metodų taikymo gydytojų profesinèje veikloje galimybès.

6. Sveikatos apsaugos raidoje paternalistinį mąstymą keičia gydytojo ir paciento bendradarbiavimo santykiai. Šiame santykyje pacientas yra gerai informuotas, reiklus ir kritiškai vertinantis gydytojo veiklą. Atsisakant paternalistinio mąstymo ir prisitaikant prie pokyčių, svarbus vaidmuo tenka gebejimams, kurių gydytojai nẻra igiję universitetuose. Todèl gydytojo profesinis parengimas turètų apimti ir psichologinių kompetencijų ugdymą.

\section{Literatūra}

1. Labanauskas, L.; Justickis, V.; Sivakovaitè, A. İstatymo įvykdomumas. Šiuolaikinè gydytojo atsakomybės didinimo tendencija. Socialiniu mokslu studijos. 2010, 4(8): 89107.

2. Catino, M.; Celotti, S. The problem of defensive medicine: two Italian surveys. Studies in Health Technology Information. 2009, 148: 206-221.

3. Esposto, A. Tort Reform, Defensive Medicine, and the Diffusion of Diagnostic Technologies. Eastern Economic Journal. 2008, 34: 141-157.

4. Kessler, D.; McClellan, M. Do doctors practice defensive medicine? Quarterly Journal of Economics. 1996, 111(2): 353-390.

5. Studdert, D. M. Defensive Medicine Among High-Risk Specialist Physicians in a Volatile Malpractice Environment. JAMA. 2005, 293: 2609-2617.

6. Xiao-Yang, Chen. Defensive Medicine or Economically Motivated Corruption? A Confucian Reflection on Physician Care in China Today. Journal of Medicine and Philosophy. 2007, 32: 635-648.

8. Katz, M. H . Study Design and Statistical Analysis: A PracticalGuide for Clinicians. Cambridge University Press, 2006.

9. Rabe-Hesketh, S. Classical latent variable models for medical research. Statistical Methods in Medical Research. 2008, 17: 5-32.

10. Abdi, H.; Williams, L. J. Principal component analysis. Wiley Interdisciplinary Reviews: Computational Statistics. 2010, 2: 433-459.

11. Justickis, V. Data mining. Handbook of electronic security and digital forensic LondonNew Jersey-Bejing, 657-692.

12. Bohm, G.; Zech, G. Introduction to Statistics and Data Analysis for Physicians. Verlag Deutsches Elektronen-Synchrotron. 2010, 201-218. 


\title{
Defensive Medicine in Lithuanian Health Care: Development of Doctors' Defensive Reactions
}

\author{
Liutauras Labanauskas \\ Lithuanian University of Health Sciences, Lithuanian Medical Association, Lithuania \\ Viktoras Justickis \\ Mykolas Romeris University, Lithuania
}

Aistė Sivakovaite

Lithuanian Medical Association, Lithuania

\section{Summary}

Defensive medicine is a flawed health care phenomenon, when the main doctor's priority becomes the striving to protect himself against possible legal prosecution for possible errors in diagnosis and treatment. The article analyses sources of doctors' defensive responses in a given clinical situation.

The article continues the presentation of the results of 2440 Lithuanian doctors' study (2011-2012). The previous article introduced its general results, whereas the current one discusses differences of defensive reactions in different medical specialties and further differences that are caused by individual characteristics of a physician, patient and a clinical situation. Examiningdifferencesindefensivereactionsindifferentspecialties, itwasfound that ahighlevelof defensive reactions were inherent in all medical specialties investigated. Therefore, in Lithuanian health care, there do not exist any 'safe' specialties, which do not use defensive medicine to protect themselvesfromprosecutionactions. Thestudyalsoidentifiesthemostsensitive(insecure) medical specialties (generalpracticephysicians, internalmedicinespecialists, pediatricians, neurologists). An important result of the study was large differences (variance) of defense reactions within each specialty. It turned out that even within a single specialty physicians may react very differently depending on the features of an individual doctor, patient and a clinical situation. In order to clarify the interaction between these characteristics, factor analysis (principal component method with Oblimin rotation) has been carried out.

This analysis made it possible to discover two fundamental factors responsible for the interaction between different traits of a doctor, patient and a clinical situation and play the crucial role in the development of defensive reactions of doctors.

The outcomes of the study showed a highly important role of grass-root psychological, ethical and cultural relations between doctor and patient in both arising and depressing of defensive medicine. The study showed that some doctors were quite successful in solving patient's confidence problems and this way is 'immune' from factors and effects causing defense medicine. A doctor who is able to understand patient's feelings (also his distrust) has incomparably better conditions to overcome this distrust. On the contrary, a doctor who sees patient's distrust as an expression of his hostility has no other option than to defend and to use defensive medicine methods.

This provided the basis for the concept of the 'double-aetiology' of defense medicine with legal and social factors acting on the societal level and quite different psychological ones prevailing on the interpersonal doctor-patient level.

Keywords: defensive medicine, doctors' defensive reaction, clinical situation, defensive medicine prevention events. 
Liutauras Labanauskas, Lietuvos sveikatos mokslų universiteto ligoninès Kauno klinikos

Vaikų gastroenterologijos sektoriaus vadovas. Moksliniai interesai: medicina, pediatrija, chirurgija, visuomenès sveikata.

Viktoras Justickis, Mykolo Romerio universiteto Socialinès politikos fakulteto Psichologijos katedros profesorius. Moksliniai interesai: sveikatos apsaugos teise ir psichologija.

Aistė Sivakovaitė, Lietuvos gydytojų sąjungos atsakingoji sekretorè. Moksliniai interesai: visuomenès sveikata, medicinos teisè, meditacija.

Liutauras Labanauskas, Lithuanian University of Health Sciences, Kaunas Clinics Hospital, Head of Children's Gastroenterology sector. Research interests: medicine, pediatrics, surgery, healthcare in society.

Viktoras Justickis, Mykolas Romeris University, Faculty of Social Policy, Department of Psychology, Professor. Research interests: medical law and psychology.

Aistė Sivakovaitė, Lithuanian Medical Association, Senior Secretary. Research interests: healthcare in society, medical law, mediation. 